\title{
PENINGKATAN AKURASI KLASIFIKASI SENTIMEN ULASAN MAKANAN AMAZON DENGAN BIDIRECTIONAL LSTM DAN BERT EMBEDDING
}

\author{
David Junggu Manggala Pasaribu ${ }^{1}$, Kusrini $^{2}$, Sudarmawan $^{3}$ \\ Program Studi Magister Teknik Informatika, Universitas Amikom Yogyakarta ${ }^{1,2,3}$ \\ Email : manggala.david@gmail.com ${ }^{1}$, kusrini@amikom.ac.id ${ }^{2}$, sudarmawan@amikom.ac.id ${ }^{3}$
}

\begin{abstract}
ABSTRAK
Revolusi industri 4.0 dengan infrastuktur internet semakin memadai dan biaya lebih murah mengakibatkan banyak masyarakat menggunakan layanan internet. Organisasi bisnis terdisrupsi untuk merambah ke media online seperti Amazon. Amazon perusahaan $e$ commerce meliputi Costumer to Costumer maupun Business to Business, salah satu produk yang dipasarkan adalah makanan karena kebutuhan primer manusia. Untuk menaikkan pemasukannya maka perusahaan harus mengerti kebutuhan pembeli, sehingga dilakukan analisis sentimen konsumen pada makanan menggunakan Natural Language Processing. Mesin tidak mudah untuk mengenal bahasa manusia, maka dikembangkan metode yang lebih akurat agar hasil klasifikasi tidak mengandung kesalahan penafsiran ulasan pada objek Amazon Food, menggunakan metode penghasil vektor kata Bidirectional Encoder Representations from Transformers dengan ulasan yang telah di praproses WordPieces dan di estraksi fitur oleh Bidirectional Long Short-Term Memory menuju ke Full Connected Layer untuk diklasifikasi ulasan negatif atau positif yang menghasilkan akurasi atau keakuratan hasil klasifikasi sentimen. Hasil penelitian tentang analisis sentimen pada dataset Amazon Fine Food Review menggunakan metode deep learning Bidirectional Long Short-Term Memory dengan penghasil vektor kata Bidirectional Encoder Representations from Transformers mampu menghasilkan akurasi yang lebih baik pada konfigurasi ukuran vektor embedding dan jumlah dataset paling besar yaitu 300 dan 85.000 sebesar $93 \%$. Peningkatan akurasi lebih baik daripada menggunakan metode penelitian sebelumnya dengan dataset Amazon Fine Food Review, seperti model Machine learning Logistic Regression dengan pembobotan kata Mutual Information dan Bag of Words serta model deep learning Convolutional Neural Network dan Long Short-Term Memory dengan penghasil vektor kata Word2Vec dan GloVe. Produsen makanan Amazon dapat mengetahui sentimen konsumen lebih akurat.
\end{abstract}

Kata Kunci: amazon fine food review, analisis sentimen, Bidirectional Encoder Representations from Transformers, Bidirectional Long Short-Term Memory, Word2Vec.

\section{ABSTRACT}

The industrial revolution 4.0 with increasingly adequate internet infrastructure has resulted in many people using internet.. Business organizations are being disrupted to venture into online media. Amazon e-commerce company one of the products marketed is food because of human primary needs. To increase its income, the company must understand the needs of the buyers, so an analysis of consumer sentiment on food. Processing. Machines are not easy to recognize human language, so a more accurate method was developed so that the classification results do not contain misinterpretation of reviews on Amazon Food objects, using the Bidirectional Encoder Representations from Transformers word vector generator 
method with reviews that have been preprocessed by WordPieces and extracted features by Bidirectional Long Short-Term Memory goes to the Full Connected Layer to be classified as negative or positive reviews which result in accuracy or accuracy of sentiment classification results. The results of research on sentiment analysis on the Amazon Fine Food Review dataset using the Bidirectional Long Short-Term Memory deep learning method with the word vector generator Bidirectional Encoder Representations from Transformers are able to produce better accuracy on the size of the embedding vector and the largest number of datasets is 300 and 85,000, 93\%. Improved accuracy is better using previous research methods with the Amazon Fine Food Review dataset, such as Machine learning Logistic Regression with weighting of words Mutual Information and Bag of Words and Convolutional Neural Network deep learning models and Long Short-Term Memory with word vector generators Word2Vec and GloVe.

Keywords: amazon fine food review, sentiment analysis, Bidirectional Encoder Representations from Transformers, Bidirectional Long Short-Term Memory, Word2Vec.

\section{PENDAHULUAN}

Tingkat penetrasi pengguna internet secara global mencapai $51 \%$ (Meeker 2019). Peningkatan efektifitas dan efisiensi maka tata cara atau teknik yang dilakukan manusia untuk melakukan kegiatan akan berubah misalnya saja penjual dan pembeli saling bertatap muka, namun karena ada media yang lebih mudah yaitu internet maka banyak perusahaan yang terdisrupsi dan mulai menambah saluran pemasaran produknya melalui internet.

Amazon merupakan perusahaan internet $B 2 B$ (Business to Business) maupun C2C (Costumer to Costumer), menyediakan tempat sebagai perantara terjadinya proses jual dan beli dari produsen ke konsumen salah satunya adalah penjualan makanan. Makanan adalah kebutuhan primer bagi manusia maka sangat penting sekali dalam bisnis makanan yang akan mendatangkan pembeli. Untuk meningkatkan keuntungan maka produsen harus mengerti kebutuhan konsumen, diperlukan teknik yang cepat dan otomatiasi untuk mengetahui sentimen dari konsumen terhadap makanan yang dibeli di Amazon menggunakan NLP
(Natural Language Processing). Komputer tidak dapat langsung memahami kandungan arti dari kalimat yang disampaikan oleh manusia. Dalam mengklasifikasikan sentimen positif dan negatif komputer belajar dari ulasan konsumen sehingga terbentuk model yang dapat mengklasifikaikan ulasan konsumen. Karena mesin tidak seperti manusia yang sudah mengerti akan bahasanya sendiri, maka metode NLP harus dapat mengklasifikasikan ulasan dengan akurasi yang tinggi agar tidak terjadi kesalahan penafsiran yang akan menyebabkan kesalahan pengambilan kebijakan dalam perusahaan. Para peneliti kemudian melakukan penelitian tentang metode $N L P$ menggunakan machine learning serta deep learning dari ulasan Amazon Fine Food agar akurasi dapat lebih besar.

Penelitian oleh Anees et al. (2019) melakukan analisis sentimen terhadap ulasan Amazon Fine Food menggunakan metode SVM, Logistic Regression dan Naive Bayes dengan berbagai macam teknik pembobotan kata seperti TFIDF, TFICF, MI dan CHI menghasilkan akurasi tertinggi Logistic Regression dengan 
pembobotan kata MI sebesar $78.11 \%$. Penelitian selanjutnya sama menggunakan machine learning namun memiliki metode lebih bervariasi, Prabhavathi (2019) melakukan analisis sentimen terhadap dataset Amazon Fine Food Review. Menggunakan teknik klasifikasi Naive Bayes, K-Nearest Neighbour, Logistic Regression, Decision Tree dan Random Forest. Dengan tiga macam pembobotan kata yaitu BOW, TF-IDF dan W2V. Menghasilkan akurasi tertinggi pada Logistic Regression dengan pembobotan BOW sebesar $90 \%$.

Dari kedua penelitian menggunakan machine learning diatas, akurasi pada penelitian Anees et al. (2019) masih kecil dibawah $90 \%$ dan pada penelitian Prabhavathi (2019) sudah baik $90 \%$ namun masih dapat ditingkatkan sehingga terdapat penelitian yang menggunakan deep learning. Penelitian dari Chemchem, Alin \& Krajecki (2019) menggunakan 6 macam metode machine learning Bernoulli NB, Multinomial NB, Linear SVM, KNN Uniform, KNN Distant, MPL NN dan satu metode deep learning Convolutional Neural Network. Dengan penghasil vektor kata yang dilatih dari dataset Amazon Fine Food Review menggunakan Word Embedding Word2Vec sebesar 100 dimensi fitur vektor per kata. Akurasi tertinggi menggunakan deep learning $\mathrm{CNN}$ yaitu 90,03\%. Peneliti lain yang menggunakan deep learning Zhou and $\mathrm{Xu}$ (2016) menganalisis sentimen positif dan negatif terhadap dataset Amazon Fine Food Review menggunakan metode Long ShortTerm Memory (LSTM) dengan berbagai skenario uji coba, dengan rasio regulasi 0.004 dan 0,001, ukuran embedding sebesar 50 dan 100, learning rate 0.005 dan 0.001 dan probabilitas droput sebesar 0.85 dan 0.9. Menghasilkan vektor tiap kata menggunakan GloVe, dimana dataset Amazon Fine Food Review dilatih untuk menghasilkan vektor berdimensi rendah. Akurasi paling tinggi yaitu pada LSTM dengan ukuran embedding 100, rasio regulasi 0.001 , learning rate 0.001 dan probabilitas dropout 0.9 sebesar $0.89 \%$.

Gap Analysis yang penulis sampaikan yaitu pada penelitian Anees et al. (2019) hasil akurasi tertinggi menggunakan pembobotan kata MI (Mutual Information) dengan hasil nilai kata yang dihitung berdasarkan keterkaitan kata tersebut dengan kata lainnya dan beserta hubungan kelas atau label tersebut. Namun kelemahannya disini adalah penentuan keterkatian dari kata yang sama tersebut melalui seluruh ulasan berdasar jumlah kata terhadap labelnya sehingga semakin banyak kata tersebut pada suatu ulasan dan memiliki label yang sama berarti kata tersebut memiliki asosiasi yang kuat terhadap label tersebut. Namun meskipun kata tersebut sama, belum tentu memiliki arti yang sama seperti kata "stick" dapat berarti tongkat atau juga menempeli, arti dari kata tersebut tergantung dari konteks kalimat, sehingga penyamaan kata yang sama antara semua dokumen akan terjadi kesalahan pemahaman. Karena sifat yang linieritas Logistic Regression dari variabel dependen dan independen maka jika ada ulasan yang ambigu antara positif dan negatif akan sulit untuk mengklasifikasikannya.

Penelitian Prabhavathi menggunakan metode Logistic Regression, tetapi dengan pembobotan Bag of Words. Metode ekstraksi fitur yang simpel secara 
one-hot encoding, vektor setiap ulasan berisi vektor sepanjang jumlah kata unik bila kata pada vektor tersebut terdapat pada ulasan maka diberi nilai 1 jika tidak ada maka 0 , tidak banyak informasi yang terkandung dalam vektor yang merepresentasikan ulasan tersebut. Penelitian terbaru akan menggunakan penghasil vektor kata Contextual Word Embedding BERT (Bidirectional Encoder Representations from Transformers) yang menghasilkan fitur berdimensi rendah yang menitik beratkan pada konteks kalimat tersebut. Jadi kata yang sama belum tentu mempunyai vektor kata yang sama tergantung konteks dari ulasan. Pada pemrosesan fitur kata untuk dikenali menggunakan Bidirectional Long SortTherm Memory, yaitu model deep learning yang bekerja secara sekuensial. BERT akan sesuai dengan deep learning yang merupakan word Embedding, dimana menghasilkan fitur berdimensi rendah namun mempunyai informasi yang padat tidak seperti MI, one-hot encoding dan BoW pada penelitian sebelumnya.

Penelitian Chemchem, Alin \& Krajecki (2019) menggunakan CNN dan Word Embedding Word2Vec sebagai penghasil fitur vektor kata dan penelitian Zhou \& Xu (2016) menggunakan LSTM dan Word Embedding Glove yang di latih sendiri. Penelitian terbaru menggunakan BiLSTM dimana terdapat dua LSTM yang dilatih dan mampu mendapatkan representasi ulasan dari kata terdahulu dan kedepan, sedangkan penelitian terdahulu hanya menggunakan satu arah LSTM dan juga model CNN yang baik untuk deteksi gambar namun untuk teks terdapat pengurangan informasi karena proses $\mathrm{CNN}$ yang downsampling. Penggunaan
Word2Vec merupakan Word Embedding yang memiliki vektor kata dimensi rendah yang padat informasi namun hanya berdasarkan kedekatan antara kata satu dengan lainnya, belum tentu kata satu itu artinya sama dengan kata lainnya sehingga dalam BERT dilakukan penambahan vektor kata sama tersebut dengan konteks kalimat yang berbeda, hal itu juga sama dengan Word Embedding GloVe. Terlebih lagi jika vektor GloVe dilatih terlebih dahulu pada dataset sendiri dengan jumlah sedikit, pada penelitian terbaru menggunakan pretrained BERT yang dapat meningkatkan akurasi karena sudah dilatih dari Wikipedia dan Book Corpus yang besar, daripada melatih dengan dataset yang lebih kecil seperti Amazon Fine Food Review.

Keaslian dan tujuan dari penelitian ini adalah untuk meningkatkan akurasi dari penelitian sebelumnya menggunakan metode Deep Learning BiLSTM serta penghasil fitur vektor kata BERT yang menitikberatkan pada konteks suatu kalimat menggunakan dataset Amazon Fine Food Review yang sudah digunakan peneliti sebelumnya sebanyak 85.000 ulasan, karena berisi ulasan makanan di Amazon dari tahun 1999 hingga 2012. Dilakukan skenario pengujian seperti jumlah dimensi dari vektor kata (embedding vector) dan jumlah dataset untuk mengetahui konfigurasi yang dapat menghasilkan akurasi lebih tinggi.

\section{LANDASAN TEORI}

\subsection{Deep Learning}

Pengertian yang lebih luas yaitu berupa evolusi mengenai lebih banyak neuron pada jaringan, penghubung antara satu jaringan dengan jaringan lain lebih kompleks, bila pada machine learning 
jaringan saraf tiruan hanya dapat mengklasifikasi namun pada deep learning dapat melakukan ekstraksi fitur, karena semua kekompleksan tersebut maka daya komputasi juga ikut membesar (Suyanto, Ramadhani \& Mandala 2019).

\subsection{Bidirectional LSTM}

\section{Bidirectional Long Short-Term} Memory adalah perkembangan dari model LSTM dimana terdapat dua lapisan yang prosesnya saling berkebalikan arah, model ini sangat baik untuk mengenail pola dalam kalimat karena setiap kata dalam dokumen diproses secara sekuensial, karena ulasan dapat dipahami bila pembelajaran secara berurut setiap kata. Lapisan dibawahnya bergerak maju (forward), yaitu memahami dan memproses dari kata pertama menuju kata terakhir sedangkan lapisan diatasnya bergerak mundur (backward), yaitu memahami dan memproses dari kata terakhir menuju kata pertama. Dengan adanya lapisan dua arah yang saling berlawanan ini maka model dapat memahami dan mengambil perspektif dari kata terdahulu dan kata terdepan, sehingga proses pembelajaran akan semakin dalam yang berdampak pada model akan lebih memahami konteks pada ulasan tersebut.

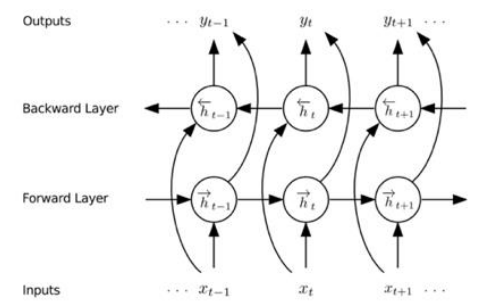

Gambar 1. Arsitektur Bidirectional LSTM

(Graves, Jaitly \& Mohamed 2013)

Dapat dilihat pada gambar 1 bahwa setiap hidden unit keluaran unit $h_{t}$ pada lapisan bawah dan atas di digabungkan membentuk nilai fitur kata tersebut dengan ukuran lebih panjang daripada menggunakan LSTM biasa. Karena lebih panjangg nilai fitur, maka informasi yang akan di proses pada tahap selanjutnya yaitu feed forward neural akan mengklasifikasikan dengan lebih akurat.

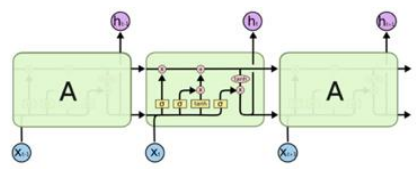

\section{Gambar 2. Arsitektur LSTM}

Gambar 2 adalah arsitektur dari LSTM, jalur bagian bawah disebut cell gates fungsinya untuk meregulasi informasi yang akan dikeluarkan ke unit berikutnya atau ke cell state. Cell state adalah jalur bagian atas untuk mengirimkan informsai ke unit lain tanpa halangan.

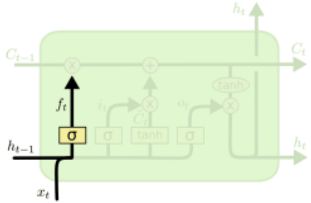

Gambar 3. Forget Gate Layer

$$
f_{t}=\sigma\left(W_{f} \cdot\left[h_{t-1}, x_{t}\right]+b_{f}\right)
$$

Persamaan (1) untuk menghitung keluaran dari lapisan Forget Gate, dimana informasi akan dihapus dan informasi yang penting akan diteruskan ke cell state.

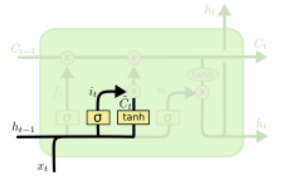

Gambar 4. Input Gate Layer

$$
\begin{aligned}
& i_{t}=\sigma\left(W_{i} \cdot\left[h_{t-1}, x_{t}\right]+b_{i}\right) \\
& \tilde{C}_{t}=\tanh \left(W_{C} \cdot\left[h_{t-1}, x_{t}\right]+b_{C}\right)
\end{aligned}
$$

Persamaan (2) untuk memasukkan nilai yaitu informasi yang akan diarahkan cell state. 


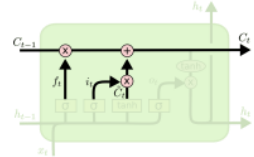

Gambar 5. Update Gate Layer

$$
C_{t}=f_{t} * C_{t-1}+i_{t} * \tilde{C}_{t}
$$

Persamaan (4) untuk mengubah nilai pada cell state yang didapat dari dua lapisan sebelumnya dari proses penghapusan dan penambahan informasi.

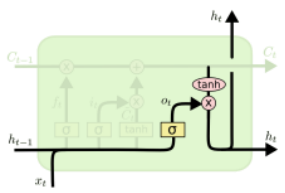

Gambar 6. Output Gate Layer

$$
\begin{aligned}
& o_{t}=\sigma\left(W_{o} \cdot\left[h_{t-1}, x_{t}\right]+b_{o}\right) \\
& h_{t}=o_{t} * \tanh \left(C_{t}\right)
\end{aligned}
$$

Persamaan (5) untuk mengeluarkan hasil yang sesuai untuk diarahkan ke hidden unit berikutnya.

\subsection{Feed Forward Layer}

Bila BiLSTM merupakan lapisan bertugas untuk mengetraksi fitur penting maka lapisan feed forward akan mengklasifikasikan fitur ulasan tersebut apakah masuk ke sentimen positif dan negatif, sehingga sangat penting untuk mengekstrak fitur dari ulasan yang merepresentasikan kalimat tersebut agar hasil klasifikasi akurat.

\subsection{Fungsi Aktivasi}

Fungsi aktivasi bekerja seperti reseptor, menunggu rangsangan dan meresponnya dengan efek tertentu. Sehingga sebagai penyaring nilai yang masuk menjadi keluaran dengan rentang tertentu, rentang tersebut mengubah data yang non-linier menjadi linier sehingga proses lapisan berikutnya akan lebih mudah. Terdapat dua fungsi aktivasi yang digunakan : a. ReLU

Restricted Linear Unit (ReLU)

berfungsi untuk memproses masukan non linier. Bila masukan dari lapisan sebelumnya dibawah nol atau sama dengan nol maka keluaran akan nol, bila masukan bernilai daitas nol maka keluarannya nilai itu sendiri (Buduma 2017). Digunakan pada lapisan tersembunyi. Persamaan yang digunakan sebagai berikut.

$$
f(x)=\max (0, x)
$$

b. Sigmoid

Semakin kecil masukan maka keluaran akan mendekati nilai nol jika masukan semakin besar maka keluaran akan mendekati nilai satu. karena akan mengklasifikasi sentimen positif dan negaitf atau disebut klasifikasi biner sehingga keluaran sigmoid sebagai probabilitas positif dan negatif antara nilai 0 dan 1 . Penambahan probabilitas hasil klasifikasi positif dan negatif akan menghasilkan nilai 1. Dihitung melalui persamaan (8).

$$
f(z)=\frac{1}{1+e^{-z}}
$$

\subsection{Optimasi Adam}

Untuk menghasilkan proses pembelajaran yang optimal maka diperlukan optimasi seperti Adam. Adam melakukan optimasi pada proses perubahan berat menggunakan gradient descent, yaitu merubah learning rate yang ditetapkan secara dinamis, sehingga akan terhindar dari gradient descent terjebak pada minimum lokal. Perbandingan performa dengan berbagai jenis optimasi gradien descent yang terbaik adalah Adam(Kingma \& Ba 2015). 
Dengan model dan dataset besar maka Adam bekerja secara efisien dan merekomendasikan menggunakan Adam (Ruder 2016).

\subsection{Pretrained BERT}

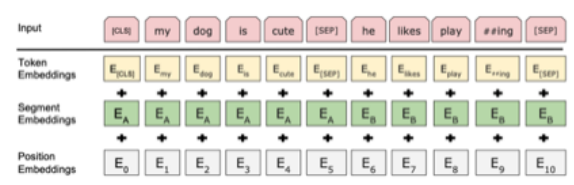

Gambar 7. Masukan pada BERT

Dalam penelitian ini menggunakan model BERT BASE yang sudah dilatih dari 2,5 juta Wikipedia dan 8 juta Book Corpus (Kiros et al. 2015). Spesifikasi jumlah layer 12, ukuran dimensi vektor 768 dan total parameter $110 \mathrm{M}$. Model menggunakan transformer sebagai perkembangan dari LSTM dapat menyelesaikan dengan sangat baik masalah NLP (Devlin et al. 2019).

\subsection{Binary Cross Entropy}

Berfungsi untuk menghtiung nilai error dari prediksi model terhadap data latih dan data uji, jika nilai error besar maka masih banyak kesalahan pada model tersebut untuk memahami pola ulasan pada dataset. Penelitian ini mengklasifikasi polar target yaitu sentimen positif dan negatif atau yang menghasilkan keluaran diantara dua probabilitas maka menggunakan Binary Cross Entropy. Persamaan (9) untuk menghtiung Binary Cross Entropy (Ramos et al. 2018). $H(P, Q)=-\operatorname{sumxin} X P(x) * \log (Q(x)$ (9)

BCE dihitung setiap batch, jika ingin mengetahui nilai error per epoch maka nilai error seluruh batch di rata-rata selama satu epoch. Persamaan (10) untuk menghtiung akurasi yang didasari pada nilai error.

acc $=100 *(1-$ error $)$

\section{METODE PENELITIAN}

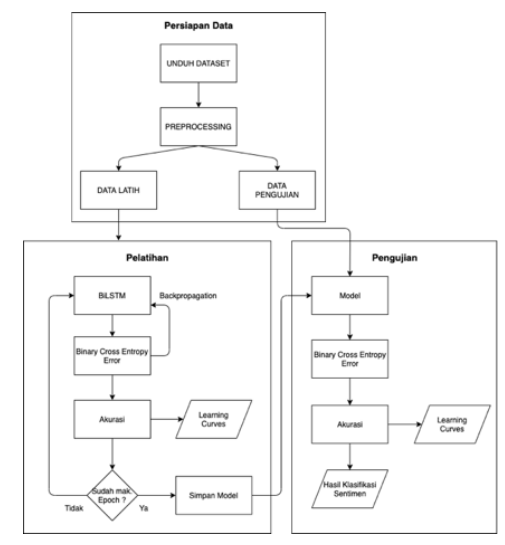

Gambar 8. Alur Penelitian

\subsection{Skenario Uji}

3.1.1 Ukuran Vektor Embedding

Tabel 1. Skenario Uji Ukuran Vektor Kata

\begin{tabular}{lc}
\hline Metode & Ukuran Vektor Embedding \\
\hline BiLSTM & 140 \\
+ BERT & 220 \\
& 300 \\
\hline
\end{tabular}

Uji perbandingan ukuran vektor embedding karena ingin mengetahui dampak dari banyak fitur yang terdapat pada suatu kata dengan hasil akurasi klasifikasi. Dilatih dengan dataset 85.000, rasio 80:20 pembagian data latih 68.000 dan data uji 17.000

\subsubsection{Jumlah Dataset}

Tabel 2. Skenario Uji Jumlah Dataset

\begin{tabular}{lc}
\hline Metode & Jumlah Dataset \\
\hline BiLSTM & 34.000 \\
+ BERT & 59.500 \\
& 85.000 \\
\hline
\end{tabular}

Uji perbandingan dengan variasi jumlah dataset pada metode dengan ukuran vektor embedding yang memilki akurasi tertinggi uji coba ke-1. Untuk mengetahui dampak dari perbedaan jumkah dataset terhadap hasil akurasi klasifikasi. Setiap jumlah dataset dibagi data latih dan data uji sebear rasio 80:20. 


\subsection{Persiapan Data}

\subsubsection{Unduh dataset}

Dataset diambil dari penelitian (Anees et al. 2019) yang didapat dari Kaggle, merupakan datasset publik dan semua orang dapat mengundunya. Berisi 568.454 ulasan dari Amazon Fine Food. Data diambil selama 12 tahun dari Oktober 1999 sampai Oktober 2012.

\section{Tabel 3. Dataset Amazon Fine Food}

\begin{tabular}{lc}
\hline \multicolumn{1}{c}{ review } & sentiment \\
\hline It was terrible it tasted like & negative \\
sugar in gelatin... & \\
This is a good tasting K-cup & positive \\
from a guy who... & \\
\hline
\end{tabular}

\subsubsection{Preprocessing}

\section{a. Penghapusan Ulasan}

Dari banyak kolom pada data ulasan hanya diambil kolom review dan sentiment. Pada kolom review yang memiliki isi sama dihapus serta ulasan jika pada kolom review dan sentiment tidak ada isinya atau kosong maka baris ulasan tersebut dihapus.

b. Normalisasi Distribusi

Perhitungan perbandingan banyaknya ulasan positif dan negatif. Karena polaritasnya buruk atau tidak sebanding maka disetarakan antara ulasan positif dan negatif masingmasing sebanyak 85.000 ulasan.

c. Konversi ke Huruf Kecil

Agar proses manipulasi perkata berikutnya lebih mudah maka semua ulasan di konversi menjadi huruf kecil dan penghapusan simbol atau tanda baca yang tidak ada arti.

d. WordPieces

WordPieces melakukan pemisahan ulasan menjadi kata dengan kombinasi berbagai prefiks dan sufiks. Pemisahan tersebut tanpa melalui proses perubahan kekata dasar seperti Stemming dan Lemmatezing ataupun penghapusan dari kata hubung seperti on, at, that. Pada umumnya jika menggunakan penghasil vektor kata biasa (General Word Embedding) seperti Word2Vec, Doc2Vec dan Gloove tahap pra proses tersebut penting dilakukan karena untuk mengurangi data yang tidak memiliki makna untuk diproses oleh komputer namun pada peneliitan ini menggunakan penghasil vektor kata secara kontekstual (Contextual Word Embedding) menggunakan BERT, dimana kata-kata tersebut penting untuk mencari vektor setiap kata yang sesuai dengan konteks kalimat.

e. Vektorisasi

Setelah vektor dari setiap kata sudah didapat maka vektor tersebut di hubungkan kedalam masing-masing ulasan. Masing-masing kata pada ulasan tersebut berisi nilai indeks integer yang merepresentasikan urutan dari Vektor kata yang telah di hasilkan oleh Contextual Word Embedding BERT. Setelah ulasan menjadi nilai integer semua maka komputer dapat mulai memproses untuk memahami atau belajar dari setiap ulasan tersebut.

f. Pemisahan Data Latih dan Uji

Untuk melakukan pelatihan pada ulasan digunakan data latih dan agar hasil evaluasi dari akurasi tersebut tidak bias, maka diperlukan validasi. Validasi yang berisi data uji yang belum pernah dilihat oleh komputer pada saat pelatihan, sehinga dengan adanya validasi tersebut akurasi yang diterima akan berlaku bagi data objek. Pemisahan dilakukan pada data ulasan yang sudah berisi vektor nilai integer. 


\subsubsection{Pelatihan}

Tabel 4. Rancangan Model

\begin{tabular}{cc}
\hline Urutan & Lapisan \\
\hline 1 & bert_layer \\
2 & Bidirectional LSTM \\
& (units=64) \\
3 & Dense (Feed Forward) \\
\hline
\end{tabular}

Pada tabel 4 menunjukan model yang digunakan untuk melakukan pelatihan dimana BiLSTM menggunakan unit sebesar 64, sehingga sebanyak 64 unit BiLSTM diparalel dan di proses bersamaan yang hasil akhirnya akan digabungkan kembali. Menggunakan ukuran batch 8 dan learning rate 0,00001.

\section{a. Lapisan BiLSTM}

Melakukan esktraksi fitur yang berjalan secara sekuensial melalui dua arah yaitu forward dari kata depan sampai akhir dan backward dari kata belakang sampai awal. Dilakukan penggabungan dua fitur nilai dan operasi fungsi aktifasi ReLU.

b. Lapisan Feed Forward

Setelah fitur terhadap ulasan didapatkan maka diklasifikasikan ke dalam Feed Forward yang akan mengeluarkan satu keluaran. Keluaran di fungsi aktivasi Sigmoid untuk menghasilkan probabilitas positif dan negatif dari nilai 0 hingga 1 .

c. Evaluasi

Menghitung nilai error dari hasil prediksi model terhadap data latih dan data uji menggunakan Binary Cross Entropy, setelah didapat nilai error maka dihitung nilai akurasi dengan mengurangi error dengan nilai 1 dan dikali 100 agar berbentuk persen. Setelah didapat akurasi satu epoch maka dilakukan perbaikan pembelajaran dengan gradient descent untuk merubah nilai berat pada masing-masing neuron sebelumnya. Proses diulang hingga epoch terakhir yaitu 5 .

\section{HASIL DAN PEMBAHASAN}

Untuk mencapai tujuan penelitian dan mengetahui performa dari model maka dilakukan pengujian melalui skenario ukuran vektor embedding dan jumlah dataset. Pengujian dilakukan pada Kaggle yaitu lingkungan interaktif python dengan spesifikasi GPU Tesla P100 16 GB dan RAM 13 GB.

\subsection{Pengujian Ukuran Embedding}

Tabel 5. Perbandingan Ukuran Embedding

\begin{tabular}{|c|c|c|c|}
\hline No & Metode & $\begin{array}{c}\text { Ukuran } \\
\text { Embedding }\end{array}$ & $\begin{array}{c}\text { Akurasi } \\
(\%)\end{array}$ \\
\hline \multirow[t]{3}{*}{1.} & BiLSTM + & 140 & $92,21 \%$ \\
\hline & $B E R T$ & 220 & $92,41 \%$ \\
\hline & & 300 & $93 \%$ \\
\hline 2. & $\begin{array}{l}\text { LR + MI } \\
\text { (Anees et al. } \\
\text { 2019) }\end{array}$ & & $78,11 \%$ \\
\hline 3. & $\begin{array}{l}\mathrm{LR}+\mathrm{BOW} \\
\text { (Prabhavathi } \\
\text { 2019) }\end{array}$ & & $90 \%$ \\
\hline 4. & $\begin{array}{l}\text { CNN + } \\
\text { Word2Vec } \\
\text { (Chemchem, } \\
\text { Alin \& } \\
\text { Krajecki 2019) }\end{array}$ & & $90,03 \%$ \\
\hline 5. & $\begin{array}{l}\text { LSTM + } \\
\text { GloVe } \\
\text { (Zhou \& Xu } \\
\text { 2016) }\end{array}$ & & $89 \%$ \\
\hline
\end{tabular}

Dapat dilihat pada tabel 5 bahwa metode BiLSTM dengan BERT menggunakan ukuran embedding 300 menghasilkan akurasi lebih tinggi daripada ukuran 220 dan 140. Semakin panjang dimensi vektor dari kata maka informasi yang merepresentasikan tentang kata 
tersebut juga semakin lengkap. Hal ini akan mempengaruhi dalam proses pembelajaran dan menemukan pola dalam ulasan tesebut yang mengakibatkan akurasinya menjadi tinggi.

Perbandingan akurasi terhadap machine learning bahwa metode BiLSTM dengan Contextual Word Embedding BERT menghasilkan akurasi yang lebih tinggi daripada penelitian Anees et al. (2019) menggunakan Logistic Regression serta Mutual Information dan penelitian Prabhavathi (2019) dengan Logistic Regression serta Bag of Words. Kemudian penelitian dengan deep learning Chemchem, Alin \& Krajecki (2019) menggunakan CNN dan Word2Vec hingga Zhou \& Xu (2016) menggunakan LSTM dan Word EMbedding GloVe. Membuktikan bahwa penggunaan Contextual Word Embedding BERT untuk penghasil fitur vektor kata yang sesuai konteks kalimat yang diproses dengan deep learning seperti BiLSTM mampu meningkatkan akurasi secara signifikan. Jelas telihat bahwa metode LSTM dari Zhou \& Xu (2016) akurasi lebih rendah 3 $\%$ terhadap BiLSTM, karena BiLSTM terdapat dua lapisan LSTM yang bergerak saling berlawanan dari kata pertama hingga kata terakhir (forward) dan dari kata terakhir ke kata pertama (backward), sehingga proses pembelajaran model akan lebih mengenal konteks kalimat yang akan meningkatkan kekauratan hasil klasifikasi sentimen positif dan negatif.

Tabel 6. Confusion Matrix

\begin{tabular}{|c|c|c|c|}
\hline $\begin{array}{c}\text { Label } \\
\text { Aktual }\end{array}$ & Negatif & 8.066 & 434 \\
\cline { 2 - 4 } & Positif & 756 & 7.744 \\
\hline \multirow{2}{*}{} & Negatif & Positif \\
\cline { 3 - 4 } & \multicolumn{2}{|c|}{ Label Prediksi } \\
\end{tabular}

Confusion Matrix pada tabel 6 yang dihasilkan dari prediksi terhadap model BiLSTM dan BERT Embedding dengan ukuran embedding yang menghasilkan akurasi sebesar $93 \%$ terhadap data uji atau validasi sebanyak 17.000. Sebanyak 8.500 ulasan negatif data di klasifikasikan negatif dengan benar sebanyak 8066 dan diklasifikasikan positif 434. Sebanyak 8.500 ulasan positif diklasifikasikan positif dengan benar sebanyak 7.744 dan di klasifikasikan salah atau negatif sebanyak 756. Maka dapat dilihat perbedaan antara sentimen yang benar diklasifikasikan negatif sebanyak $0,948 \%$ dan diklasifikasikan salah sebanyak 0,052\%. Diklasifikasikan benar positif sebanyak $0,911 \%$ dan yang dillasifikasikan salah atau negatif $0,089 \%$. Presentase keakuratan yang di klasifikasikan oleh model benar positif lebih tinggi 0,948\% daripada yang diklasifikasikan benar negatif $0,911 \%$. Keakuratan klasifikasi terhadap sentimen positif lebih besar pada ulasan makanan Amazon, makanan yang seharusnya tidak enak diklasifikasikan menjadi enak lebih baik daripada makanan enak tapi diklasifikasikan tidak enak.

\subsection{Pengujian Jumlah Dataset}

Tabel 7. Perbandingan Jumlah Dataset

\begin{tabular}{clcc}
\hline No & Metode & $\begin{array}{c}\text { Jumlah } \\
\text { Dataset }\end{array}$ & $\begin{array}{c}\text { Akurasi } \\
\mathbf{( \% )}\end{array}$ \\
\hline 1 & BiLSTM + & 34.000 & $91,84 \%$ \\
& BERT + 300 & 59.500 & $92,32 \%$ \\
& Dimensi & 85.000 & $93 \%$
\end{tabular}

Pada tabel 7 pengujian menggunakan jumlah dataset berbeda seperti 34.000, 59.400 dan 85.000 dengan rasio pembagian data latih dan uji sebesar 80:20 menghasilkan akurasi pada dataset terebsar sampai terkecil yaitu $93 \%, 92,32 \%$ dan 
91,84\%. Semakin banyak jumlah dataset maka akurasi juga turut meningkat, karena model deep learning seperti BiLSTM akan dapat terus belajar dan meningkatkan akurasinya bila datasetnya semakin banyak tidak seperti metode machine learning dimana jika terlalu banyak dimensi fitur maka dapat terjadi "Curse of Dimensionality" dimana model tersebut tidak dapat lagi untuk menaikan akurasi bahkan dapat menurunkannya. Dalam BiLSTM semakin banyak dataset berarti semakin banyak variasi data yang dapat dipelajari untuk merubah berat dari model. Jika model BiLSTM di lakukan prediksi pada data yang belum terlihat maka akurasinya menjadi semakin tinggi.

\section{SIMPULAN DAN SARAN}

Dari hasil penelitian maka dapat dihasilkan kesimpulan dan saran sebagai berikut.

\subsection{Kesimpulan}

Dari hasil pengujian menggunakan model deep learning BiLSTM serta Contextual Word Embedding BERT dengan konfigurasi ukuran embedding sebesar 300 dan jumlah dataset 85.000 mendapatkan akurasi lebih baik daripada menggunakan Word Embedding biasa seperti Word2Vec dan GloVe dengan model deep learning CNN dan LSTM dengan akurasi $93 \%$. Hal ini karena proses ekstraksi vektor kata yang menitik beratkan pada konteks kalimat tersebut sehingga menghasilkan representasi nilai yang baik dari kata tersebut untuk di proses ke dalam deep learning. Serta proses pembelajaran dua arah dari BiLSTM, model dapat lebih mengerti pola kalimat hasilnya dapat mengurangi kesalahan klasifikasi dalam ulasan makanan Amazon. Produsen makanan pada Amazon mendapatkan sentimen dari konsumen dengan keakuratan yang lebih tinggi untuk meningkatkan keuntungan.

\subsection{Saran}

Dilakukan variasi pengujian pengukuran vektor embedding lebih banyak sampai 500 vektor embedding untuk mengetahui pola hasil akurasinya.

\section{DAFTAR PUSTAKA}

Anees, Aiman Abdullah et al. 2019. "Performance Analysis of Multiple Classifiers Using Different Term Weighting Schemes for Sentiment Analysis." 2019 International Conference on Intelligent Computing and Control Systems, ICCS 2019 (Iciccs): 637-41.

Buduma, Nikhil. 2017. Fundametals of Deep Learning: Designing NextGeneration Machine Intelligence Algorithms. Sebastopol: O'Reilly Media, Inc.

Chemchem, Amine, François Alin, and Michael Krajecki. 2019. "Improving the Cognitive Agent Intelligence by Deep Knowledge Classification." International Journal of Computational Intelligence and Applications 18(1): 1-25.

Devlin, Jacob, Ming Wei Chang, Kenton Lee, and Kristina Toutanova. 2019. "BERT: Pre-Training of Deep Bidirectional Transformers for Language Understanding." NAACL HLT 2019 - 2019 Conference of the North American Chapter of the Association for Computational Linguistics: Human Language Technologies - Proceedings of the Conference 1(Mlm): 4171-86.

Graves, Alex, Navdeep Jaitly, and Abdelrahman Mohamed. 2013. "Hybrid Speech Recognition with Deep Bidirectional LSTM Alex Graves , Navdeep Jaitly and Abdel-Rahman 
Mohamed University of Toronto Department of Computer Science 6 King' s College Rd . Toronto , M5S 3G4, Canada." : 273-78.

Kingma, Diederik P., and Jimmy Lei Ba. 2015. "Adam: A Method for Stochastic Optimization." 3rd International Conference on Learning Representations, ICLR 2015 Conference Track Proceedings: 1-15.

Kiros, Ryan et al. 2015. "Skip-Thought Vectors." Advances in Neural Information Processing Systems 2015-January(786): 3294-3302.

Meeker, Mary. 2019. "BOND Internet Trends 2019." 2019-06-11: 333. https://www.bondcap.com/report/itr1 9/\#view/1.

Prabhavathi, C. 2019. "Machine Learning Model for Classifying L _ Text Using Nlp ( Amazon Product Reviews )." 6(04): 161-78.

Ramos, Daniel, Javier Franco-Pedroso, Alicia Lozano-Diez, and Joaquin
Gonzalez-Rodriguez.

2018.

"Deconstructing Cross-Entropy for Probabilistic Binary Classifiers." Entropy 20(3).

Ruder, Sebastian. 2016. "An Overview of Gradient Descent Optimization Algorithms." : : 1-14. http://arxiv.org/abs/1609.04747.

Suyanto, K. N. Ramadhani, and S. Mandala. 2019. Deep Lerning: Modernisasi Machine Learning Untuk Big Data. Bandung: Informatika.

Zhou, Zhenxiang, and Lan Xu. 2016. "Amazon Food Review Classification Using Deep Learning and Recommender System." Stanford University: 1-7. https://cs224d.stanford.edu/reports/Zh ouXu.pdf. 